\title{
Kinerja Keuangan Dan Nilai Perusahaan: Peran Ukuran Perusahaan Perbankan Konvensional Di BEI
}

\author{
Ikhwan $^{1}$, Syamsul Ridjal ${ }^{2}$ dan La Ode Sumail ${ }^{3}$ \\ ${ }^{1}$ Mahasiswa Magister Manajemen STIEM Bongaya \\ ${ }^{2-3}$ Dosen Sekolah Tinggi Ilmu Ekonomi Makassar (STIEM) Bongaya
}

Email Addres:

ikhwan.9117@gmail.com; ridjalsyamsul@yahoo.com:odesumail@stiem-bongaya.ac.id

\begin{abstract}
Abstrack: This study investigates the relationship between BOPO and NPL with financial performance (ROA) and the impact on firm value using signaling theory analysis. In addition, what is also to be achieved is to investigate the role of firm size as a moderating variable and a mediating variable. The research sample was 16 banks that met the criteria (purposive sampling) with 80 observations. BOPO and NPL can be suppressed so as to encourage ROA. Furthermore, ROA can drive TQ. SIZE can strengthen ROA so that TQ becomes high in the market. In addition, ROA is able to push SIZE. And SIZE is able to contribute to TQ. SIZE has a positive and significant role in mediating between ROA and TQ.
\end{abstract}

Keyword: BOPO, NPL, ROA, SIZE, TQ.

\begin{abstract}
Abstrak: Penelitian ini menyelidiki hubungan BOPO dan NPL dengan kinerja keuangan (ROA) serta berdampak pada nilai perusahaan dengan pisau analisis signaling theory. Selain itu, yang ingin dicapai pula adalah meninvestigasi peran ukuran perusahaan sebagai variabel moderasi dan variabel mediasi. Sampel penelitian sebanyak 16 bank yang memenuhi kriteria (purposive sampling) dengan pengamatan berjumlah 80. BOPO dan NPL dapat ditekan sehingga dapat mendorong ROA. Selanjutnya, ROA dapat dapat mendorong TQ. SIZE dapat memperkuat ROA sehingga TQ menjadi tinggi di pasar. Selain itu, ROA mampu mendorong SIZE. Dan SIZE mampu berkontribusi terhadap TQ. SIZE bereperan positif dan signifikan memediasi antara ROA dan TQ.
\end{abstract}

Kata kunci: BOPO, NPL, ROA, SIZE, TQ.

\section{PENDAHULUAN}

Kinerja keuangan merupakan potret bahwa bank dikelola dengan baik. Manajemen memiliki tanggungjawab untuk mengelola sumberdaya keuangan bank agar menghasilkan kinerja keuangan yang baik serta dapat mendorong nilai perusahaan. Sebaliknya, ketika bank tidak dikelola dengan baik maka akan menghasilkan kinerja keuangan yang tidak sehat sehingga akan menurunkan harga saham perusahaan atau nilai perusahan menjadi menurun. Harga saham sebagai cerminan nilai perusahaan. Tentunya, pasar akan merespon positif jika harga saham tinggi. Berbeda kasus, jika harga saham turun maka pasar direspon negatif sehingga nilai perusahan turun. Investor akan membuat keputusan apakah harga saham yang 
ditawarkan perusahaan merupakan harga saham yang mahal atau murah. Salah satu ukuran nilai perusahaan menggunakan Tobins $Q$. Ketika Tobins $Q$ berada diatas nilai 1, investor menilai harga saham mahal. Sebaliknya, jika nilai Tobins $Q$ berada dibawah nilai 1, boleh jadi investor menilai harga saham murah (Damodaran 2001 dikutip oleh Gumanti 2017). Oleh karena itu, antara kinerja keuangan dan nilai perusahaan memiliki keterkaitan sehingga isu tentang nilai perusahaan menarik untuk dilakukan penelitian.

Banyak faktor yang mempengaruhi sehat tidaknya kinerja keuangan bank. Antara lain, Capital, Asset, Management, Earning and Liquidity (CAMEL), Operational Efficiency Ratio (OER) atau BOPO, Capital Adequacy Ratio (CAR), Net Interest Margin Ratio (NIMR), likuiditas, profitabilitas (ROA), Loan to Deposit Ratio (LDR), risiko profil perusahaan atau Non Performing Loan (NPL), ukuran perusahaan dan lain-lain (Institute for Development of Economic and Finance/INDEF-2005, dikutip oleh Harun, 2016).

Fakta menunjukan bahwa tren kinerja keuangan berupa ROA beberapa bank mengalami naik turun dibandingkan dengan rasio industri perbankan. Dapat dipastikan ROA memiliki keterkaitan dengan nilai perusahaan. Kenyataanya, ada beberapa bank pada periode tertentu ROA berada dibawah rata-rata industri yang berarti belum sehat atau belum sesuai dengan harapan pemegang saham. Hal ini dicurigai disebabkan oleh BOPO dan NPL. Ketika BOPO mengalami kenaikan, ROA cenderung menurun dan nilai perusahaan turun. Sebaliknya, jika BOPO mengalami penurunan, ROA cenderung meningkat dan nilai perusahaan naik. Penelitian sebelumnnya, seperti (ChyntiaOvami, 2017; Raharjo, Setiaji, \& Syamsudin, 2014; Sudiyatno \& Setiyowati, 2012) menemukan bahwa semakin rendah BOPO semakin tinggi ROA. Namun, (Harun, 2016; Haryati \& Widyarti, 2016; Lestari \& Setianegara, 2020; Raharjo et al., 2014; Sudarmawanti \& Pramono, 2017) menemukan bahwa semakin tinggi BOPO semakin tinggi ROA. Oleh karena itu, BOPO yang cenderung rendah dapat mendorong ROA sehingga nilai perusahaan meningkat.

Dari kondisi empiris bahwa kinerja keuangan tidak saja ditentukan oleh BOPO. Tetapi, faktor risiko profil perusahaan (NPL) yang memiliki keterkaitan dengan kinerja keuangan (ROA). Ada beberapa bank pada periode tertentu memperlihatkan NPL tinggi diatas arata-rata industri sehingga menurunkan kinerja ROA. Ketika manajemen bank mampu menekan risiko, boleh jadi ROA perusahaan meningkat dan nilai perusahaan tinggi. Penelitian sebelumnya (Haryati \& Widyarti, 2016) menemukan bahwa NPL berpengaruh negatif terhadap ROA. Namun ada juga yang berpandangan lain, seperti (Harun, 2016; Sudarmawanti \& Pramono, 2017) menemukan bahwa risiko profil perusahaan atau NPL tidak berpengaruh signifikan terhadap kinerja keuangan atau ROA.

Tentunya, kinerja keuangan bank yang baik merupakan potret bahwa bank telah dikelola dengan baik melalui efisiensi BOPO dan menekan NPL sehingga bank akan mendapatkan respon positif dari pasar atau investor. Respon positif tersebut akan dicerminkan oleh kenaikan harga saham sehingga nilai peusahaan tinggi. Hipotesis yang pernah diajukan oleh (Nurminda, Isynuwardhana, \& Nurbaiti, 2017; Rachmawati \& Pinem, 2015; Yunina \& Husna, 2018) menemukan bahwa semakin baik kinerja keuangan semakin tinggi nilai perusahaan. Berbeda (Santosa, Aprilia, \& Tambunan, 2020) menemukan bahwa kinerja keuangan tidak dapat berkontribusi terhadap nilai perusahaan.

Berdasarkan kondisi obejktif dan adanya pertentangan hasil penelitian sebelumnya maka motivasi penelitian ini adalah (1) meletakan variabel efisiensi (BOPO) dan risiko profil perusahaan (NPL) sebagai variabel independen terhadap kinerja keuangan (ROA) 
sebagai variabel dependen dengan pisau analisis menggunakan teori signaling, (2) Karena kinerja keuangan memiliki keterkaitan dengan nilai perusahaan maka penelitian ini merumuskan model hubungan kinerja keuangan dengan nilai perusahaan dimoderasi dan dimediasi dengan ukuran perusahaan. Oleh karena itu, penelitian ini memiliki alasan meletakan ukuran perusahaan sebagai variabel moderasi dan sebagai variabel mediasi sekaligus menjadi pembeda dengan penelitian sebelumnya.

Alasan pertama, meletakan ukuran perusahaan sebagai variabel moderasi karena ketika ukuran perusahaan besar akan memperkuat profitabilitas serta memperkuat nilai perusahaan. Peneliotian (Vijaykumar, 2010) bahwa ukuran perusahaan muncul sebagai faktor penting yang mempengaruhi profitabilitas serta nilai perusahaan. Hal ini juga dikemukakan oleh (Olaniyi \& Simon-oke, 2017) bahwa hubungan ukuran perusahaan dengan profitabilitas terjadi hubungan dua arah. Artinya ukuran perusahaan dapat berkontribusi terhadap profitabilitas, lalu profitabilitas dapat berkontribusi terhadap ukuran perusahaan. Berbeda dengan penelitian (Singla, 2011) menemukan bahwa kontribusi ukuran perusahaan terhadap nilai perusahaan cenderung lemah. Dengan demikian, peran ukuran perusahaan yakni lemah antara hubungan ROA dengan nilai perusahaan.

Alasan kedua, meletakan ukuran perusahaan sebagai variabel mediasi karena ketika bank berhasil mencetak kinerja keuangan (ROA) yang tinggi maka akan memperbesar total asset sehingga pasar merespon secara positif, harga saham naik dan nilai perusahaan tinggi. Penelitian (Batra, 2016; Bolarinwa, 2017) mengemukakan bahwa profitabilitas dapat menjelaskan terhadap ukuran perusahaan. Kemudian, studi (Indriyani, 2017; Lidia dan Juniarti, 2015) menemukan bahwa ukuran perusahaan dapat berkontribusi terhadap nilai perusahaan.

Melalui kondisi objektif dan perdebatan hasil penelitian sebelumnya serta motivasi penelitian maka tujuan penelitian ini berusaha menemukan jawaban hubungan BOPO dan NPL dengan kinerja keuangan (ROA) serta berdampak pada nilai perusahaan. Selain itu, yang ingin dicapai pula adalah meninvestigasi peran ukuran perusahaan sebagai variabel moderasi dan mediasi. Semua hubungan antar variabel akan dibedah dengan pisau analisis signaling theory.

\section{KAJIAN TEORI}

Institute for Development of Economic and Finance (INDEF-2005) dikutip oleh Harun, 2016) bahwa ada banyak ukuran-ukuran kinerja keuangan bank. Antara lain, Capital, Asset, Management, Earning and Liquidity (CAMEL), likuiditas, profitabilitas, risiko profil perusahaan atau Non Performing Loan (NPL), termasuk ukuran perusahaan dan lain-lain. Penelitian ini tertarik pada dua aspek yakni BOPO, NPL, ROA dan ukuran perusahaan.

Biaya Operasional dan Pendapatan Operasional (BOPO) dan Kinerja keuangan (ROA): BOPO atau Operational Efficiency Ratio (OER) Operational efficiency ratio merupakan alat ukur kesehatan bank yakni perbandingan antara beban atau biaya operasional terhadap pendapatan operasional suatu perusahaan pada periode tertentu (Fakhruddin \& Purwanti, 2015). Dengan kata lain BOPO merupakan kemampuan bank dalam mengelola beban operasionalnya. Semakin besar beban operasional, berarti semakin 
buruk tatakelola bank tersebut (Lestari \& Setianegara, 2020). Jika rasio BOPO mengalami penurunan dari tahun sebelumnya dapat dikatakan operasional bank tersebut semakin efisien. Sebaliknya, jika rasio BOPO mengalami kenaikan dari tahun sebelumnya tentunya operasional bank tersebut semakin tidak efisien. Kriteria BOPO adalah 50\% - 75\% (sangat sehat), $76 \%$ - 93\% (sehat), 94\% - 96\% (cukup sehat), 96\% - 100\% (tidak sehat) dan $>100 \%$ (tidak sehat) sesuai SEBI No.6/23/DPNP tanggal 31 Mei 2004.

Sesuai dengan ketentuan Bank Indonesia, rasio BOPO yang ideal berada antara 5075\%. BOPO memiliki ketrekaitan dengan kinerja keuangan (ROA). Apabila ROA tinggi berarti bank tersebut telah dikelola dengan baik sehingga menghasilkan kinerja keuangan yang baik. Sebaliknya, ROA rendah berarti bank tersebut tidak dikelola dengan baik sehingga menghasilkan kinerja keuangan yang rendah atau tidak sehat. Tentunya, prestasi yang dipeoleh dari proksi ROA yang cenderung baik berate bank tersebut telah mengelola beban operasionalnya dengan efisien. Penelitian (Chyntia Ovami, 2017; Raharjo et al., 2014; Sudiyatno \& Setiyowati, 2012) menemukan bahwa BOPO terhadap kinerja keuangan tetapi masih lemah. Berbeda dengan penelitian (Harun, 2016; Haryati \& Widyarti, 2016; Lestari \& Setianegara, 2020; Raharjo et al., 2014; Sudarmawanti \& Pramono, 2017) menyatakan bahwa BOPO mampu mendorong kinerja keuangan secara signifikan. Oleh karena itu, hipotesis penelitian ini:

\section{H1: BOPO berhubungan negatif dan signifikan dengan kinerja keuangan (ROA).}

Risiko profil perusahaan dan Kinerja keuangan (ROA): Risiko profil perusahaan atau Non Performing Loan (NPL) merupakan ukuran kesehatan aset suatu bank. Bahkan ada yang mengatakan bahwa NPL dapat memberikan informasi penilaian terhadap kondisi likuiditas, permodalan, rentabilitas, risiko kredit, serta risiko pasar atas suatu bank. Apabila NPL tinggi yang berarti bank tidak mampu mengelola kualitas asset sehingga kondisi asset bank cenderung buruk dan berdampak pada kinerja keuangan. Sebaliknya, NPL rendah adalah potret bahwa bank mampu mengelola kualitas asset sehingga kondisi asset bank menampilkan wajah sehat dan kinerja keuangan akan semakin sehat. NPL identik dengan risiko kredit merupakan kecenderungan kegagalan debitur membayar kewajibannya atau debitur tidak dapat melunasi kewaajibannya (Fakhruddin \& Purwanti, 2015).

Indikator Non Performing Loan (NPL) yaitu: 0\% - 2\% (sangat sehat), 2\% - 3,5\% (sehat), 3,5\% - 5\% (cukup sehat), 5\% - 8\% (kurang sehat) dan $>8 \%$ (tidak sehat). Dengan demkian, semakin rendah NPL semakin sehat, begitu pula sebaliklnya. Kemampuan bank menekan NPL akan mendorong ROA. Penelitian (Haryati \& Widyarti, 2016) menemukan bahwa NPL berpengaruh negatif terhadap ROA. Sementara, (Harun, 2016; Sudarmawanti \& Pramono, 2017) menemukan bahwa risiko profil perusahaan atau NPL tidak berpengaruh signifikan terhadap kinerja keuangan atau ROA. Maka hipotesis yang diajukan adalah:

H2: NPL berhubungan negatif dan signifikan terhadap kinerja keuangan (ROA).

Kinerja keuangan dan nilai perusahaan: Potret apakah perusahaan telah dikelola dengan baik atau tidak akan menghasilkan kinerja keuangan. Dapat pula dikatakan bahwa kinerja keuangan yang baik adalah prestasi yang diperoleh perusahaan. Misalnya, kemampuan menghasilkan profitabilitas (ROA). Ketika ROA bank tinggi, nilai perusahaan akan 
meningkat. Nilai perusahaan dicerminkan oleh harga saham. Apabila harga saham naik dari akibat ROA yang tinggi dapat dipastikan nilai perusahaan meningkat. Sebaliknya, ROA rendah, harga saham akan rendah dan nilai perusahaan rendah pula. Tinggi rendahnya nilai perusahaan dapat diukur melalui proksi Tobin's Q, Ada pula yang menggunakan price earning ratio (PER) dan price to book value (PBV). Penelitian (Nurminda et al., 2017; Rachmawati \& Pinem, 2015; Yunina \& Husna, 2018) menemukan bahwa kinerja keuangan dapat menjelaskan secara signifikan terhadap nilai perusahaan. Berbeda dengan penelitian (Santosa et al., 2020) menemukan bahwa nilai perusahaan tidak ditentukan lagi oleh kinerja keuangan. Karena itu, hipotesis penelitian yakni:

H3: Kinerja keuangan (ROA) berhubungan positif dan signifikan dengan nilai perusahaan.

Nilai perusahaan akan kuat jika ada peran ukuran perusahaan dan kinerja keuangan. Ukuran perusahaan diproksikan oleh total asset. Ketika total asset besar maka ada sumber dana perusahaan untuk membiayai investasi produktif sehingga menghasilkan ROA yang tinggi atau kuat sehingga dapat mendorong nilai perusahaan dan menjadi kuat. Karena itu, hipotesis penelitian adalah:

H4: Kinerja keuangan (ROA) berpengaruh positif dan signifikan terhadap nilai perusahaan dimoderasi ukuran perusahaan.

Kinerja keuangan bank dan ukuran perusahaan: Total asset merupakan proksi dari ukuran perusahaan. Besar kecilnya ukuran perusahaan diproksikan dengan total asset. Semakin besar total asset berarti semakin besar ukuran perusahaan. Sebaliknya, semakin kecil total asset berarti semakin kecil ukuran perusahaan. Antara ROA dan ukuran perusahaan memiliki keterkaitan. Apabila ROA tinggi, cenderung akan mendorong ukuran perusahaan. Sebalinya, ketika ROA rendah boleh jadi ukuran perusahaan rendah. Penelitian (Batra, 2016; Bolarinwa, 2017) mengemukakan bahwa profitabilitas berhubungan positif dan signifikan dengan ukuran perusahaan. Berbeda (Olaniyi \& Simon-oke, 2017; Vijaykumar, 2010) menemukan bahwa profitabilitas berpengaruh negatif dan signifikan terhadap ukuran perusahaan. Jadi hipotesis penelitian adalah:

\section{H5: Kinerja keuangan (ROA) berhubungan positif dan signifikan dengan ukuran perusahaan.}

Ukuran perusahaan dan nilai perusahaan: Kemampuan bank memperbesar asset akan mendorong nilai perusahaan. Sebalinya, ukuran perusahaan bank yang cenderung kecil dapat dipastikan rendah atau kecil dalam mendorong nilai perusahaan. Investor akan tertarik berinvestasi ketika bank memiliki ukuran perusahaan besar. Sebab, ukuran perusahaan besar, harga saham tinggi dan nilai perusahaan tinggi. Sebaliknya, investor kurang tertarik untuk berinvestasi pada bank yang memiliki ukuran perusahaan yang cenderung kecil karena return yang harapkan kecil. Penelitian (Indriyani, 2017; Lidia dan Juniarti, 2015) menjelaskan bahwa ukuran perusahaan dapat berkontribusi terhadap peningkatan nilai perusahaan. Berbeda dengan (Singla, 2011) menemukan bahwa ukuran perusahaan dapat berkontribusi terhadap nilai perusahaan tetapi lemah. Selanjutnya, (Haryanto, Rahadian, 
Mbapa, Rahayu, \& Febriyanti, 2018) menemukan bahwa nilai perusahaan tidak ditentukan lagi oleh ukuran perusahaan. Maka hipotesis penelitian yaitu:

H6: Ukuran perusahaan berhubungan positif dan signifikan dengan nilai perusahaan.

Dapat dipastikan bahwa besar kecilnya ukuran perusahaan ditentukan oleh ROA. Bank yang mampu mencetak ROA tinggi akan dapat mendorong total asset sehingga nilai perusahaan meningkat. Pasar dan investor akan merespon positif jika bank mampu mencetak ROA dan dapat mendorong ukuran perusahaan serta dapat meningkatkan nilai perusahaan. Sebaliknya, bank yang cenderung menghasilkan ROA rendah maka ukuran perusahaan rendah dan nilai perusahaan rendah pula. Sehingga hipoetsis yang diajukan adalah:

H7: Kinerja keuangan (ROA) berhubungan positif dan signifikan dengan nilai perusahaan dimediasi ukuran perusahaan

\section{METODOLOGI}

Sampel penelitian sebanyak 16 bank yang memenuhi kriteria (purposive sampling) yakni bank yang menerbitkan laporan kinerja keuangan secara lengkap tahun 2016-2020. Oleh karena itu jumlah pengamatan 80. Untuk mendapat informasi yang akurat maka penelitian ini menggunakan analisis regresi.

Table 1. Deskripsi variabel dan pengukuran

\begin{tabular}{ll}
\hline Variabel & Pengukuran \\
\hline BOPO & Beban operasi dibagi pendapatan operasional x 100\% \\
NPL & Kredit bermasalah dibagi kredit yang disalurkan x 100\% \\
Kinerja keuangan (ROA) & Laba bersih dibagi total asset x 100\% \\
Ukuran perusahaan & Ln total aset \\
Nilai perusahaan (TQ) & Tobins Q \\
$\beta_{1}, \beta_{2}, \beta_{3}, \beta_{4}, \beta_{5}$, & Koefisien regresi \\
& \\
Keterangan: Penggunaan pengukuran sesuai dengan kondisi objektif pada bank konvensional \\
\hline
\end{tabular}




\section{HASIL PENELITIAN}

Analisis Deskriptif. Penelitian ini menyajikan analisis statistik deskriptif seperti Tabel 2 yakni mendeskripsikan data yang mengandung informasi tentang nilai rata-rata (mean), minimum, maksimum dan standar deviasi (Ghozali,2014).

Tabel 2. Statistik deskriptif

\begin{tabular}{lccccc}
\hline & N & Minimum & Maximum & Mean & Std. Deviation \\
\hline BOPO & 80 & .50 & .90 & .6529 & .10811 \\
NPL & 80 & .01 & .05 & .0313 & .01911 \\
ROA & 80 & .09 & .69 & .4394 & .16439 \\
SIZE & 80 & 10.51 & 17.71 & 13.6842 & 1.81635 \\
ROA*SIZE & 80 & 1.13 & 11.43 & 6.1265 & 2.60802 \\
TQ & 80 & .12 & 4.53 & 1.5026 & 1.38562 \\
\hline
\end{tabular}

Sumber : data sekunder diolah, 2021

Berdasarkan tabel 2 di atas menunjukkan bahwa $\mathrm{N}$ dari 80 data sampel BOPO (X1) nilai minimum sebesar 0.5000 atau $50 \%$ dan nilai maksimum sebesar 0.9000 atau $90.00 \%$, dari periode 2016-2020. Diketahui nilai rata-rata sebesar 0.6529 atau $65.29 \%$ dan nilai standar deviasi sebesar 0.10811. Ketika mean lebih besar dari nilai standar berarti penyebaran data merata dan penyimpangan data rendah. Selanjutnya, NPL (X2) dari 80 sampel diketahui bahwa nilai minimum sebesar 0.0100 atau $1,00 \%$, nilai maksimum sebesar 0.0500 atau $5.00 \%$, dan nilai mean dari periode 2016-2020 sebesar 0.0313 atau $3.13 \%$, serta nilai standar deviasi sebesar 0.01911. Artinya, nilai rata-rata NPL periode 2016-2020 lebih besar dari nilai standar berarti penyebaran data merata dan penyimpangan data rendah.

ROA (Y1) dari 80 sampel diketahui bahwa nilai minimum sebesar 0.0900 atau 9,00\%, nilai maksimum sebesar 0.6900 atau $69.00 \%$. Diketahui nilai rata-rata dari periode 20162020 sebesar 0.4394 atau $43.94 \%$, serta nilai standar deviasi sebesar 0.16439 . Artinya, nilai mean ROA periode 2016-2020 lebih besar dari nilai standar berarti transmisi data merata dan deviasi data rendah. Kemudian, SIZE (Y2) dari 80 sampel diketahui bahwa nilai minimum sebesar 10.510000, nilai maksimum sebesar 17.710 .000 dan nilai mean dari periode 2016-2020 sebesar 13.684200 serta nilai standar deviasi sebesar 1.816350. Artinya, nilai mean SIZE periode 2016-2020 lebih besar dari nilai standar berarti transmisi data merata dan deviasi data.

Tobin Q (Y3) dari 80 sampel diketahui bahwa nilai minimum sebesar 0.1200 atau $0,1 \%$, nilai maksimum sebesar 4.53 atau $4.53 \%$. Diketahui nilai mean dari periode 20162020 sebesar 1.5026 atau $1.5 \%$, serta nilai standar deviasi sebesar 1.38562 . Artinya, nilai mean TQ periode 2016-2020 lebih besar dari nilai standar berarti transmisi data merata dan deviasi data. Lalu, interaksi ROA*SIZE dari 80 sampel diketahui bahwa nilai minimum sebesar 1.1300, nilai maksimum sebesar 11.4300, dan nilai mean dari periode 2016-2020 sebesar 6.1265, serta nilai standar deviasi sebesar 2.60802. Artinya, nilai mean TQ periode 2016-2020 lebih besar dari nilai standar berarti transmisi data merata dan deviasi data,

Asumsi normalitas. Data yang memiliki distribusi data normal atau mendekati normal akan melahirkan model regresi yang baik. Gambar 1 dibawah ini menunjukkan bahwa data 
berdistribusi normal jika simpangan data berada di sekitar garis diagonal dan mengikuti garis diagonal tersebut. Oleh karena itu, penelitian ini memiliki data normal.

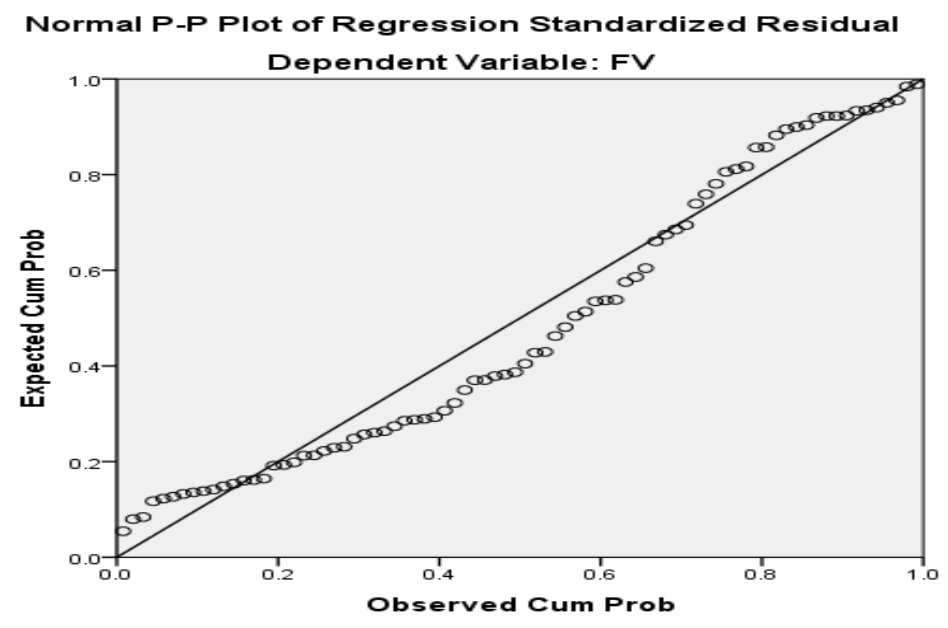

Gambar 1. Hasil Uji Normalitas dengan Menggunakan Probability Plot

Asumsi multikolineritas. Jika tidak terjadi korelasi diantara variabel independen, dapat dinyatakan sebagai model regresi yang ideal. Terlihat bahwa tidak ada nilai Tolerance di bawah 0.10 (nilai toleransi berkisar antara 0.311 sampai 0.994 , begitu juga nilai VIF tidak ada di atas 10 (nilai VIF berkisar antara 1.136 sampai 7.828). Oleh karena itu terbukti tidak ada multikolinearitas yang serius.

Tabel 3. Hasil uji multikolineritas

\begin{tabular}{|c|c|c|c|c|c|c|c|}
\hline \multirow[b]{2}{*}{ Model } & \multicolumn{2}{|c|}{$\begin{array}{c}\text { Unstandardized } \\
\text { Coefficients }\end{array}$} & \multirow{2}{*}{$\begin{array}{c}\begin{array}{c}\text { Standardized } \\
\text { Coefficients }\end{array} \\
\text { Beta } \\
\end{array}$} & \multirow[b]{2}{*}{$\mathbf{t}$} & \multirow[b]{2}{*}{ Sig. } & \multicolumn{2}{|c|}{$\begin{array}{c}\text { Collinearity } \\
\text { Statistics }\end{array}$} \\
\hline & B & Std. Error & & & & Tolerance & VIF \\
\hline 1 (Constant) & 1.683 & 3.867 & & .435 & .665 & & \\
\hline BOPO & -.023 & 1.470 & -.002 & -.016 & .988 & .880 & 1.136 \\
\hline NPL & .453 & 2.529 & .019 & .179 & .858 & .994 & 1.006 \\
\hline ROA & 9.725 & 1.467 & 1.154 & -1.302 & .197 & .615 & 7.828 \\
\hline SIZE & .015 & .265 & .019 & .055 & .956 & .596 & 4.461 \\
\hline ROA*SIZE & .634 & .557 & 1.194 & 1.139 & .259 & .311 & 4.967 \\
\hline
\end{tabular}

Dependent Variable: FV

Asumsi autokorelasi. Hasil uji autokorelasi untuk penelitian ini dapat dilihat pada tabel uji Durbin Watson. Tabel 4 di bawah ini terlihat bahwa nilai Durbin-Watson untuk penelitian ini adalah sebesar 1,863. Karena nilai tersebut terletak antara 1.55 dan 2.45 maka dapat disimpulkan bahwa penelitian ini bebas dari masalah autokorelasi. 
Tabel 4. Hasil Uji Autokorelasi

\begin{tabular}{cccccc}
\multicolumn{7}{c}{ Model Summary } \\
Model & $\boldsymbol{R}$ & $\boldsymbol{R}$ Square & $\begin{array}{c}\text { Adjusted } \boldsymbol{R} \\
\text { Square }\end{array}$ & $\begin{array}{l}\text { Std. Error of } \\
\text { the Estimate }\end{array}$ & Durbin-Watson \\
\hline 1 & $.379^{\mathrm{a}}$ & .144 & .086 & 1.32475 & 1.863 \\
\hline
\end{tabular}

Predictors: (Constant), MDR, NPL, BOPO, SIZE, ROA

Dependent Variable: FV

Uji Kebaikan Model. Uji kebaikan model menggunakan pendekatan $R$ Square. Penentuan kebaikan model melalui perhitungan nilai $\mathrm{Rm}$ atau nilai predictive-relevance diperoleh dengan rumus (Ghozali, 2014).

Model 1: $\mathrm{a}+\mathrm{b} 1 \mathrm{BOPO}+\mathrm{b} 2 \mathrm{NPL}+\mathrm{e}$

$R_{M}^{2}=1-\left(1-\mathrm{R}_{1}^{2}\right)$

$R_{M}^{2}=1-(1-0.233)$

$R_{M}^{2}=1-(0.769)$

$R_{M}^{2}=0.31$

Diperoleh nilai $R_{M}^{2}=0.31$ atau 31,00\%, jadi sekitar 31,00 keragaman dari data dapat dijelaskan oleh model. Oleh karena itu, model dikatakan baik sehingga layak penjelasan dan pengujian hipotesis dan $69 \%$ dijelaskan oleh variabel lain.

Model 2: $\mathrm{a}+\mathrm{b} 3 \mathrm{ROA}+\mathrm{b} 4$ SIZE + b4TQ + e

$R_{M}^{2}=1-\left(1-\mathrm{R}_{2}^{2}\right)\left(1-\mathrm{R}_{3}^{2}\right)\left(1-\mathrm{R}_{4}^{2}\right)\left(1-\mathrm{R}_{5}^{2}\right)\left(1-\mathrm{R}_{6}{ }^{2}\right)$

$R_{M}^{2}=1-(1-0.124)(1-0.299)(1-0.234)(1-0.182)(1-0.209)$

$R_{M}^{2}=1-(0.876)(0.701)(0.766)(0.818)(0.791)$

$R_{M}^{2}=1-(0.304)$

$R_{M}^{2}=0.696$

Diperoleh nilai $R_{M}^{2}=0.696$ atau 69,6\%, jadi sekitar 69,6 keragaman dari data dapat dijelaskan oleh model. Oleh karena itu, model dikatakan baik sehingga layak penjelasan dan pengujian hipotesis dan $30.4 \%$ dijelaskan oleh variabel lain.

Hasil Pengujian Hipotesis. Pengujian hipotesis adalah melihat seberapa besar pengaruh masing-masing variabel terikat terhadap variabel bebas, seberapa besar pengaruh peran variabel moderasi dan seberapa besar peran variabel mediasi. Untuk mengetahui tingkat signifikasi yakni membandingkan $p$ value dengan alpha 0.05 , atau membandingkan $\mathrm{t}$ statistic dengan $\mathrm{t}$ table. Penelitian ini lebih berfokus pada standar alpha 0.05. Jika $p$ value $<0.05$ maka dikatakan signifikan. Sebaliknya, jika $\mathrm{p}$ value $>0.05$ dikatakan tidak signifikan. Kemudian, dalam penelitian ini terdapat hubungan positif (searah) dan hubungan negatif (tidak searah).

Tabel 5. Pengujian hipotesis 


\begin{tabular}{lccc}
\hline Hubungan antar variabel & Koefisien jalur & P value & Keterangan \\
\hline Tanpa mediasi dan moderasi: & & & \\
BOPO $\rightarrow$ ROA & -0.246 & 0.005 & signifikan \\
NPL $\rightarrow$ ROA & -0.165 & 0.036 & signifikan \\
ROA $\rightarrow$ TQ & 0.376 & 0.037 & signifikan \\
Mediasi: & & & \\
ROA $\rightarrow$ TQ & 0.327 & 0.006 & signifikan \\
ROA $\rightarrow$ SIZE & 0.241 & 0.000 & signifikan \\
SIZE $\rightarrow$ TQ & 0.249 & 0.003 & signifikan \\
Pengaruh total: & & & signifikan \\
ROA $\rightarrow$ SIZE $\rightarrow$ TQ & 0.436 & 0.037 & signifikan \\
Moderasi: & 0.626 & & \\
ROA*SIZE & & &
\end{tabular}

Sumber: Hasil penelitian 2021

Keterangan: Pengaruh total $=$ pengaruh langsung + pengaruh tidak langsung $($ Gozali, 2014)

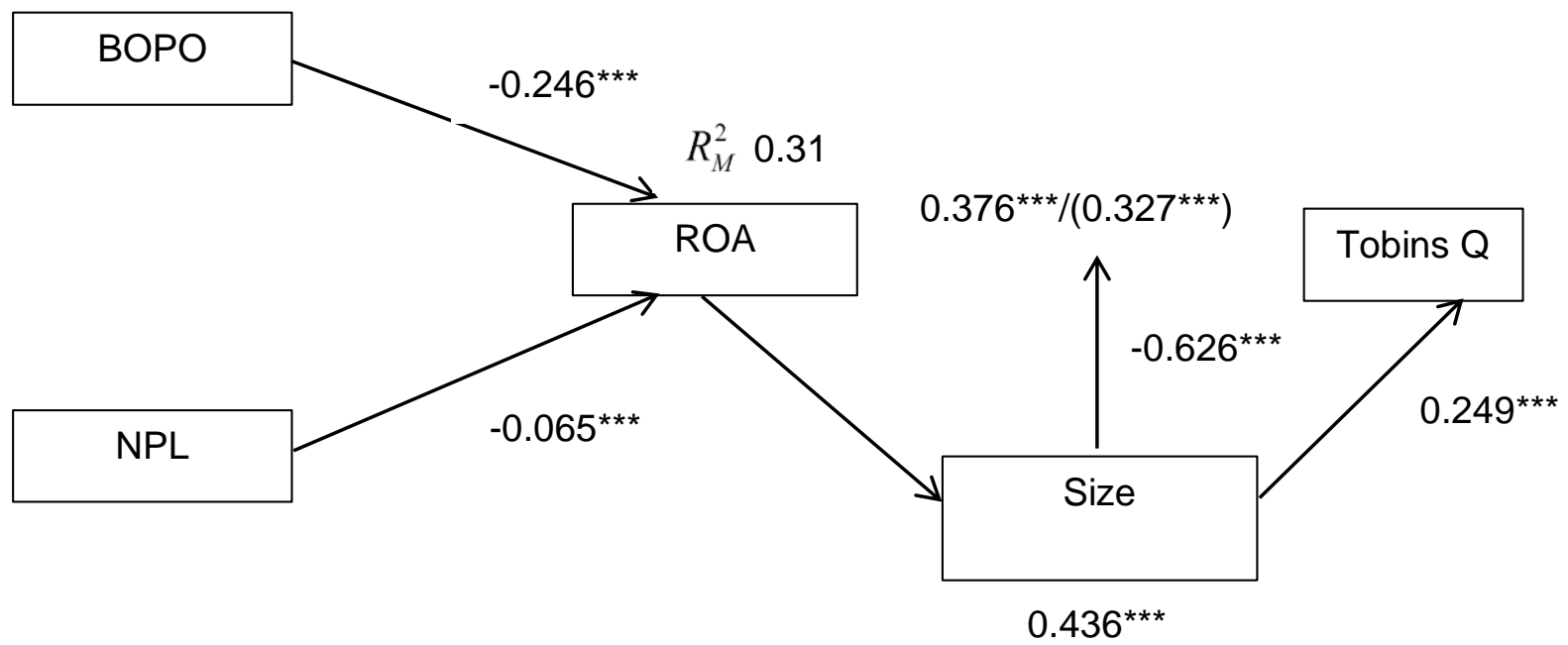

Gambar 2. Model Hasil Penelitian

Berdasarkan hasil pengujian hipotesis secara statistik pada Tabel 5 dan Gambar 2 di atas, dari 7 hipotesis yang diajukkan memperlihatkan bahwa kesemuanya dapat diterima atau didukung oleh fakta empirik.

Pengaruh moderasi (moderation effect) kinerja keuangan (ROA) $\left(\mathrm{Y}_{1}\right)$ terhadap nilai perusahaan (TQ) $\left(\mathrm{Y}_{3}\right)$ dimoderasi ukuran perusahaan (SIZE) $\left(\mathrm{Y}_{2}\right)$. Hasil analisis interaksi $\left(\mathrm{ROA}^{*} \mathrm{SIZE}\right)$ diperoleh koefisien jalur sebesar 0.626 dan probabilitas $(\mathrm{p})=0,020$ lebih kecil dari nilai $\alpha=0,05$, sehingga dikatakan signifikan. Hasil ini menunjukkan bahwa hipotesis keempat yang diajukan berbunyi: kinerja keuangan berhubungan positif dan signifikan dengan nilai perusahaan dimoderasi ukuran perusahaan. Karena itu, hipotesis diterima atau didukung oleh fakta empirik. Mengingat koefisien jalur bertanda positif, dapat diartikan 
bahwa peran (SIZE) $\left(\mathrm{Y}_{2}\right)$ semakin kuat atau tinggi dalam memperkuat ROA ( $\left.\mathrm{Y}_{1}\right)$ sehingga dapat memperkuat TQ $\left(\mathrm{Y}_{3}\right)$.karena itu, ukuran perusahaan sebagai Quasi moderasi.

Selain sebagai variabel moderasi, ukuran perusahan dapat pula berfungsi sebagai variabel mediasi. Setelah diletakan ukuran perusahaan (SIZE) $\left(\mathrm{Y}_{2}\right)$ maka diperoleh hasil pengaruh kinerja keuangan (ROA) ( $\left.\mathrm{Y}_{1}\right)$ terhadap nilai perusahaan (TQ) ( $\mathrm{Y}_{3}$ ) setelah mediasi. Dari pengujian tersebut, ketika melibatkan ukuran perusahaan sebagai variabel mediasi, nilai koefisien standardized pengaruh kinerja keuangan (ROA) terhadap nilai perusahaan (TQ) adalah 0.376. Sebelum melibatkan ukuran perusahaan sebagai variabel mediasi dan nilai koefisien standardizednya pengaruh kinerja keuangan terhadap nilai perusahaan mengalami peningkatan menjadi 0.327. Dan total pengaruh sebesar 0.436. Sesuai dengan kaidah pemeriksaan variabel mediasi, dapat disimpulkan bahwa variabel ukuran perusahaan $\left(\mathrm{Y}_{2}\right)$ dapat dikatakan sebagai variabel mediasi sebagian, untuk hubungan kinerja keuangan $\left(\mathrm{Y}_{1}\right)$ dengan nilai perusahaan $\left(\mathrm{Y}_{3}\right)$.

\section{PEMBAHASAN}

Penelitian ini menemukan bahwa BOPO dapat mendorong ROA namun masih lemah pada perbankan konvensional. Artinya, semakin rendah BOPO semakin tinggi ROA bank konvesional. Hal ini dibuktikan bahwa rata-rata BOPO bank konvensional sebesar 0.6529 atau $65.29 \%$. BOPO atau operational efficiency ratio yang ideal berada antara $50-75 \%$. Artinya, seluruh BOPO bank konvesional masih dalam kategori ideal atau sangat sehat sehingga dapat mendorong kinerja keuangan yakni ROA. Akan tetapi beberapa bank berhasil mencapai BOPO tinggi atau maksimum 90.00\%. Nilai sebesar $90.00 \%$ dapat dikategorikan sehat ketika BOPO antara 76\%-93\% adalah sehat (SEBI No.6/23/DPNP tanggal 31 Mei 2004). Bahkan ada bank yang memiliki BOPO yang terendah atau minimum sebesar 50\%. Hal ini sebagai bukti bahwa perusahaan dikelola dengan baik serta menggunakan prinsip kehati-hatian (prudential) serta mematuhi rambu-rambu operasional yang ditetapkan oleh BI dan Otoritas Jasa keuangan (OJK).

BOPO yang rendah akan mendorong kinerja keuangan (ROA). Penenlitian ini membuktikan bahwa rata-rata ROA perbankan konvensional adalah $43.94 \%$. Nilai ini menunjukan bahwa ROA bank cukup tinggi dalam menghasilkan laba hampir mendekati $50 \%$ atau dalam kategori sehat. Dengan demkian dapat dikatakan bahwa ada kemampuan bank konvensional mengelola BOPO dengan baik sehingga menghasilkan ROA yang tinggi. Adapula beberapa bank konvensional menghasilkan ROA dalam jumlah tinggi atau maksimum sebesar $69.00 \%$ dan masih ada yang memiliki ROA rendah sebesar $9.00 \%$.

Menurut Institute for Development of Economic and Finance (INDEF-2005) dikutip oleh (Harun, 2016) bank yang berkinerja dengan baik adalah mampu mengelola BOPO sehingga menghasilkan ROA. Dalam pandangan singnalling theory bahwa kemampuan bank mengelola BOPO dengan baik akan menghasilkan ROA yang tinggi. Hal ini sebagai bukti bahwa bank memberikan sinyal positif kepada pasar atau investor. Hasil penelitian ini mendukung penelitian sebelumnya dari (Chyntia Ovami, 2017; Raharjo et al., 2014; Sudiyatno \& Setiyowati, 2012) menemukan bahwa BOPO mampu mejelaskan kinerja keuangan atau ROA tetapi masih lemah. Penelitian ini tidak mendukung penelitian dari (Harun, 2016; Haryati \& Widyarti, 2016; Lestari \& Setianegara, 2020; Raharjo et al., 2014; Sudarmawanti \& Pramono, 2017) menemukan bahwa BOPO dapat berkonribusi signifikan 
terhadap ROA.

Penelitian ini menemukan bahwa risiko profil perusahaan (NPL) yang rendah dapat meningkatkan ROA. Dengan kata lain, semakin rendah NPL semakin tinggi ROA. Penelitian ini membuktikan bahwa rata-rata NPL bank konvensional adalah 3.13\%. Ini menunjukan bahwa NPL bank konvensional dalam kategori sehat. NPL yang sehat adalah antara 2\%-3,5\%. Hasil penelitian ini menemukan bahwa NPL paling rendah sebesar $1 \%$ atau sangat sehat dimana standar NPL sangat sehat antara 0\%-2\%. Kemudian NPL maksimum sebesar $5.00 \%$ atau cukup sehat. Kemampuan bank menekan NPL dapat mendorong ROA, dimana rata-rata ROA perbankan konvensional adalah $43.94 \%$. Nilai ini menunjukan bahwa ROA bank cukup tinggi dalam menghasilkan laba hampir mendekati 50\% atau dalam kategori sehat. Dengan demkian dapat dikatakan bahwa ada kemampuan bank konvensional menekan NPL dengan baik sehingga menghasilkan ROA yang tinggi. Adapula beberapa bank konvensional menghasilkan ROA dalam jumlah tinggi atau maksimum sebesar $69.00 \%$ dan masih ada yang memiliki ROA rendah sebesar $9.00 \%$ (SEBI No.13/24/DPNP/2011).

Manajemen bank konvesional memiliki kemampuan menekan NPL sehingga mampu mendorong ROA merupakan sinyal positif bagi pasar atau investor. Dalam pandangan singnalling theory bahwa kemampuan bank menekan NPL dengan baik akan menghasilkan ROA yang tinggi sebagai bukti bahwa bank dikelola dengan baik sehingga pasar atau investor memberikan respon positif. Karenanya, penelitian ini mendukung penelitian (Haryati \& Widyarti, 2016) menemukan bahwa semakinrendah NPL semakin tinggi ROA. Penelitian ini tidak mendukung penelitian (Lestari \& Setianegara, 2020) menemukan bahwa risiko profil perusahaan atau NPL berpengaruh positif dan signifikan terhadap kinerja keuangan atau ROA. Serta tidak mendukung penelitian dari (Harun, 2016; Sudarmawanti \& Pramono, 2017) menemukan bahwa risiko profil perusahaan atau NPL tidak berpengaruh signifikan terhadap kinerja keuangan atau ROA.

Penelitian ini menemukan bahwa ROA dapat menjelakan nilai perusahaan (Tobins Q). Dapat diartikan bahwa semakin tinggi ROA semakin tinggi nilai perusahaan bank konvensional. Kemampuan bank menghasilakan ROA merupakan kemampuan bank menghasilkankinerja yang baik sehingga pasar merespon positif sehingga harga saham naik dan nilai perusahaan tinggi. Prestasi ini direspon oleh pasar atau investor sehingga nilai perusahaan tinggi. Penelitian ini membuktikan bahwa rata-rata nilai perusahaan sebesar $1.5 \%$. Hal ini diperoleh karena ada kemampuan bank menghasilkan ROA yang tinggi sehingga bank konvensional memiliki Tobins Q berada diatas 1.

Menurut Damodaran dikutip oleg Gumanti (2017) bahwa Tobins Q berada diatas 1 atau dikatakan mahal dan ada juga yang berada dibawah 1 dikatakan murah. Bagi pemegang saham menganggap bahwa Tobins Q berada diatas 1 akan memberikan return yang tinggi dan dibawah 1 akan memberikan return yang rendah. Investor yang suka dengan riisiko akan berinvestasi pada perusahaan yang memiliki Tobins $Q$ yang berada diatas 1 karena mengharapkan return yang tinggi. Bagi investor yang tidak suka risiko maka tidak tertarik berinvestasi pada Tobins $Q$ yang berada diatas 1 mereka tertarik pada perusahaan yang memiliki Tobins $Q$ yang berada dibawah 1 karena murah tetapi return yang diharapkan rendah. Penelitian menemukan bahwa beberapa bank memiliki Tobins Q murah sebesar $0,1 \%$ dan menemukan Tobins Q lebih mahal sebesar $4.53 \%$. Dalam pandangan singnalling theory bahwa bank yang memiliki ROA dapat mendorong nilai perusahaan sehingga pasar 
akan merespon positif karena perusahaan memiliko kinerja keuangan atau ROA yang baik dan nilai perusahaan yang tinggi. Dengan demikian, penelitian ini mendukung penelitian dari (Nurminda et al., 2017; Rachmawati \& Pinem, 2015; Yunina \& Husna, 2018) menemukan bahwa semakin baik ROAsemakin baik nilai perusahaan (Tobins Q). Penelitian ini tidak mendukung penelitian dari (Santosa et al., 2020) menemukan bahwa nilai perusahaan (Tobins Q) tidak ditentukan lagi oleh ROA.

Penelitian ini menemukan bahwa ukuran perusahaan memiliki peran berarti dalam memperkuat ROA sehingga nilai perusahaan menjadi kuat pula. Karena ukuran perusahaan berperan menguatkan ROA sehingga nilai perusahaan semakin kuat atau tinggi. Ukuran perusahaan merupakan cerminan atas kemampuan perusahaan memiliki total aset yang dapat digunakan untuk dijadikan sumber pendanaan sehingga dapat mendorong pertumbuhan penjualan bank dan menghasilkan ROA yang kuat atau tinggi. Dengan demkian ROA yang tinggi akan mengkuatkan kinerja keuangan sehingga direspon oleh invrstor, harga saham menarik di pasar dan nilai perusahaan menjadi tinggi. Sebaliknya, jika total aset tidak mengalami pertumbuhan akan berakibat pada penurunan ROA sehingga berdampak pada nilai perusahaan. Sebagai bukti, penelitian ini menemukan bukti bahwa rata-rata ukuran perusahaan yang diproksikan total aset sebesar 13.684.200. Hal ini menunjukkan bahwa total aset dapat menguatkan ROA sehingga nilai perusahaan menjadi kuat atau tinggi. Sebagai bukti bahwa rata-rata nilai perusahaan sebesar $1.5 \%$. Ada beberapa bank yang memiliki total aset cukup tinggi diatas rata-rata sebesar 17.710.000 dan ada pula dibawah rata-rata atau minimum sebesar 10.510.000. Oleh karena itu, ukuran perusahaan dapat memperkuat hubungan ROA dengan nilai perusahaan. Terbukti interaksi ROA dengan ukuran perusahaan secara signifikan. Rata-rata interaksi tersebut sebesar 6.126.500, sehingga ukuran perusahaan sebagai Quasi moderasi merupakan variabel yang memoderasi hubungan antara ROA dan nilai perusahaan atau sebagai variabel moderasi semu berinteraksi (ROA*ukuran perusahaan) sekaligus menjadi variabel prediktor. Dalam pandangan singnalling theory bahwa bank yang memiliki total asset yang besar atau kuat akan memperkuat ROA serta memperkuat nilai perusahaan sehingga menjadi sinyal positif bagi investor.

Penelitian ini mendukung penelitian (Vijaykumar, 2010) bahwa ukuran perusahaan muncul sebagai faktor penting yang mempengaruhi profitabilitas serta nilai perusahaan. Hal ini juga dikemukakan oleh (Olaniyi \& Simon-oke, 2017) bahwa hubungan ukuran perusahaan dengan profitabilitas terjadi hubungan dua arah. Artinya ukuran perusahaan dapat berkontribusi terhadap profitabilitas dan profitabilitas dapat pula berkonribusi terhadap ukuran perusahaan. Penelitian ini tidak mendukung penelitian (Singla, 2011) menemukan bahwa ukuran perusahaan berperan lemah antara hubungan ROA dengan nilai perusahaan.

Penelitian ini menemukan bahwa semakin tinggi ROA semakin besar ukuran perusahaan. Bank yang berhasil menghasilkan ROA tinggi akan memperbesar total aset sehingga dapat membiayai kegiatan operasional bank. sehingga dapat memperbesar total asset. Bank yang berhasil menghasilkan mencetak ROA tinggi serta mampu mendorong pertumbuhan aset maka pasar dan investor akan merspon positif. Dalam pandangan singnalling theory bahwa bank yang memiliki ROA serta dapat mendorong total asset yang besar atau kuat akan menjadi sinyal positif bagi investor. Oleh karena itu, penelitian ini mendukung penelitian sebelumnya (Batra, 2016; Bolarinwa, 2017) menyatakan bahwa 
profitabilitas dapat berkontribusi terhadap ukuran perusahaan. Berbeda temuan dengan (Olaniyi \& Simon-oke, 2017; Vijaykumar, 2010) menemukan bahwa ROA berhubungan negative dan signifikan dengan ukuran perusahaan.

Studi ini menemukan bahwa ukuran perusahaan mampu berkontribusi terhadap nilai perusahaan. Sebab, semakin besar ukuran perusahaan semakin tinggi nilai perusahaan. Dengan demikian dapat dikatakan bahwa bank yang memiliki total aset yang besar akan direspon positif oleh pasar atau investor sehingga harga saham tinggi dan berdampak positif terhadap nilai perusahaan. Kemampuan bank yang dapat memperbesar total aset merupakan keberhasilan mengelola sumber daya keuangan yang baik. Oleh karena itu, prestasi ini di respon pasar dan investor karena mereka menaruh harapan bahwa ketika berinvestasi di bank konvensional, investasi akan aman dan memberikan return yang tinggi. Dalam pandangan singnalling theory bahwa bank yang memiliki kemampuan memperbesar total aset serta dapat mendorong nilai perusahaan maka menjadi sinyal positif bagi pasar dan investor. Dengan demikian, penelitian ini mendukung penelitian dari (Indriyani, 2017; Lidia dan Juniarti, 2015) menemukan bahwa ukuran perusahaan mampu mendorong secara signifikan terhadap Tobins Q. Penelitian ini tidak mendukung penelitian dari (Haryanto et al., 2018) mengemukakan bahwa nilai perusahaan tidak ditentukan lagi oleh ukuran perusahaan.

Studi ini menemukan bahwa ROA dapat mendorong nilai perusahaan jika dimediasi ukuran perusahaan. Artinya, semakin tinggi ROA semakin besar ukuran perusahaan dan nilai perusahaan meningkat. Oleh karena itu, ROA yang tinggi dapat menambah aset perusahaan sehingga total aset menjadi besas atau bertambah. Kemampuan bank memperbesar total aset merupakan prestasi bahwa bank benar-benar dikelola dengan baik. Pasar dan investor akan merespon positif atas prestasi yang dicapai oleh bank sehingga harga saham meningkat dan berdampakpada peningkatan nilai perusahaan. Dengan demikian, ukuran perusahan sangat berperan secara signifikan dalam menjembati antara kinerja keuangan dan nilai perusahaan, sehingga dapat disimpulkan bahwa ukuran perusahaan dapat dikatakan sebagai variabel mediasi sebagian, untuk pengaruh kinerja keuangan terhadap nilai perusahaan. Dalam pandangan singnalling theory bahwa bank yang memiliki kemampuan memperbesar total aset adalah bank yang memiliki kinerja keuangan yang tinggi atau baik sehingga berdampak pada peningkatan nilai perusahaan. Karena itu, penelitian ini mendukung penelitian (Batra, 2016; Bolarinwa, 2017) mengemukakan bahwa profitabilitas mampu mendorong ukuran perusahaan. Bahkan, (Indriyani, 2017; Lidia dan Juniarti, 2015) menyatakan bahwa ukuran perusahaan mampu mendorong nilai perusahaan (Tobins Q). Studi ini tidak mendukung (Olaniyi \& Simon-oke, 2017; Vijaykumar, 2010) menemukan bahwa profitabilitas yang rendah akan memperbesar ukuran perusahaan. Begitupula studi (Singla, 2011) menjelaskan bahwa ukuran perusahaan yang kecil akan dapat meningkatkan nilai perusahaan. Selanjutnya, (Haryanto et al., 2018) menyatakan bahwa ukuran perusahaan tidak dapat menjelaskan nilai perusahaan.

\section{KESIMPULAN}

Studi ini menyelidiki hubungan BOPO dan NPL dengan kinerja keuangan (ROA) serta berdampak pada nilai perusahaan. Selain itu, yang ingin dicapai pula adalah meninvestigasi peran ukuran perusahaan sebagai variabel moderasi dan mediasi. Semua 
hubungan antar variabel akan dibedah dengan pisau analisis signaling theory. Hasil penelitian menemukan bahwa efisiensi (BOPO) berpengaruh negatif terhadap kinerja keuangan (ROA) pada perbankan konvensional. Semakin rendah BOPO semakin tinggi ROA.. Selanjutnya, risiko profil perusahaan (NPL) yang rendah dapat meningkatkan kinerja keuangan (ROA) pada perbankan konvensional.

Kinerja keuangan (ROA) dapat mendorong kenaikan nilai perusahaan pada perbankan konvensional. Lalu, peran ukuran perusahaan sangat berarti dalam memperkuat ROA sehingga nilai perusahaan menjadi kuat. Kemudian, ROA dapat mendorong ukuran perusahaan sehingga menjadi besar. Selanjutnya, ukuran perusahaan dapat pula mendorong nilai perusahaan menjadi tinggi. Begitupula, ROA yang semakin tinggi akan mendorong ukuran perusahaan dan nilai perusahaan meningkat. Karena itu, peran SIZE sangat signifikan dalam memediasi hubungan antara ROA dan nilai perusahaan (TQ).

Berdasarkan penilaian kebaikan model pertama bahwa diperoleh nilai $R_{M}^{2}=0.31$ atau $31,00 \%$, jadi sekitar 31,00 keragaman dari data dapat dijelaskan oleh model dan $69 \%$ dijelaskan oleh variabel lain, seperti tatakelola, CAR, LDR, NIM dan lain-lain, sehingga menjadi peluang penelitian yang akan datang. Kemudian, kebaikan model kedua bahwa diperoleh nilai $R_{M}^{2}=0.696$ atau $69,6 \%$, jadi sekitar 69,6 keragaman dari data dapat dijelaskan oleh model dan $30.4 \%$ dijelaskan oleh variabel lain, seperti likuiditas, dividen dan lain-lain. Oleh karena itu menjadi peluang penelitian yang akan datang.

\section{REFERENSI}

Batra, R. (2016). Rethinking and Redefining the Determinants of Corporate Profitability. Global Business Review, 17(4), 1-13.

Bolarinwa, S. T. (2017). Firm Size - Profitability Nexus : An Empirical Evidence from Nigerian Listed Financial Firms. Global Business Review, 20(5), 1-13.

ChyntiaOvami, D. (2017). Faktor-Faktor Yang Mempengaruhi Kinerja Keuangan Bank Konvensional Pada Bursa Efek Indonesi. Jurnal Akuntansi Dan Bisnis, 3(1), 15-25.

Fakhruddin, I., \& Purwanti, T. (2015). Pengaruh Rasio Kesehatan Bank Terhadap Kinerja Keuangan Bank Syariah Periode 2010-2013. Kompartemen, XIII(2), 116-131.

Gozali, Imam. (2014) Ekonometrika: Teori, Konsep dan Aplikasi dengan IBM SPSS 22, Badan Penerbit Universitas Diponegoro, Semarang.

Gumanti, T.A. (2017) Keuangan Korporat; Tinjauan Teori dan Bukti Empiris, Mitra Wacana Media, Jakarta.

Harun, U. (2016). Pengaruh Ratio-Ratio Keuangan CAR, LDR, NIM, BOPO, NPL Terhadap ROA. Jurnal Riset Bisnis Dan Manajemen, 4(1), 67-82.

Haryanto, S., Rahadian, N., Mbapa, M. F. I., Rahayu, E. N., \& Febriyanti, K. V. (2018). Kebijakan Hutang, Ukuran Perusahaan dan Kinerja Keuangan Terhadap Nilai Perusahaan: Industri Perbankan di Indonesia. AFRE (Accounting and Financial Review), 1(2), 62-70.

Haryati, R., \& Widyarti, E. T. (2016). Pengaruh Leverage, Size, NPL, BOPO dan LDR Terhadap Kinerja Keuangan Bank (Studi Pada Bank Umum Konvensional Yang Terdaftar Di Bursa Efek Indonesia Periode 2010-2014). Diponegoro Journal Of Management, 5(3), 1-13. 
Indriyani, E. (2017). Pengaruh Ukuran Perusahaan dan Profitabilitas Terhadap Nilai Perusahaan. Akuntabilitas, 10(2), 333-348.

Lestari, W. D., \& Setianegara, R. G. (2020). Analisis Pengaruh Nim, Bopo, Ldr, Dan Npl Terhadap Profitabilitas (Studi Kasus Pada Bank Umum Yang Listed Di Bursa Efek Indonesia Periode 2014-2018). Keunis, 8(1), 82.

Lidia dan Juniarti. (2015). Pengaruh Ukuran Perusahaan, Leverage, Pertumbuhan Penjualan Dan Profitabilitas Terhadap Nilai Perusahaan Pada Perusahaan Yang Terdaftar Dalam Indeks Lq45.

Nurminda, A., Isynuwardhana, D., \& Nurbaiti, A. (2017). The Influence Of Profitability, Leverage, and Firm Size Toward Firm Value ( Study Of Manufacture Companies Goods And Foods Sub Sector Listed in Indonesia Stock Exchange 2012-2015 ). EProceeding of Management, 4(1), 542-549.

Olaniyi, C. O., \& Simon-oke, O. O. (2017). Re-examining Firm Size-profitability Nexus : Empirical Evidence from Non-financial Listed Firms in Nigeria. Global Business Review, 18(3), 1-16.

Rachmawati, D., \& Pinem, D. B. (2015). Pengaruh Profitabilitas, Leverage Dan Ukuran Perusahaan Terhadap Nilai Perusahaan. EQUITY, 18(1), 1-10.

Raharjo, D. P. A., Setiaji, B., \& Syamsudin. (2014). Pengaruh Rasio CAR, NPL, LDR, BOPO, Dan NIM Terhadap Kinerja Bank Umum di Indonesia. Jurnal Ekonomi Manajemen Sumber Daya, 15(2), 7-12.

Santosa, P. W., Aprilia, O., \& Tambunan, M. E. (2020). The intervening effect of the dividend policy on financial performance and firm value in large indonesian firms. International Journal of Financial Research, 11(4), 408-420.

Singla, B. K. (2011). Does Firm Size Affect Profitability? An Empirical. Paradigm, XV(1 \& 2), 18-25.

Sudarmawanti, E., \& Pramono, J. (2017). Pengaruh CAR, NPL, BOPO, NIM dan LDR Terhadap ROA (Studi kasus pada Bank Perkreditan Rakyat di Salatiga yang terdaftar di Otoritas Jasa Keuangan Tahun 2011-2015). Among Makarti, 10(19), 1-18.

Sudiyatno, B., \& Setiyowati, R. (2012). Pengaruh Bopo , Npl , Nim Dan Car Terhadap Kinerja Keuangan Bank (Studi Pada Bank-Bank Yang Listed Di Bursa Efek Indonesia). Dinamika Akuntansi Keuangan Dan Perbankan, 1(1), 57 - 73.

Vijaykumar, A. (2010). Does The Firm Size Ma Tier? An Empirical Enquiry Into The Performance Of Indian Automobile Firms. Indian Institute of Management Lucknow, 9(2), 42-54.

Yunina, Y., \& Husna, A. (2018). Pengaruh Struktur Modal Dan Kinerja Keuangan Terhadap Nilai Perusahaan Pada Perusahaan Manufaktur Sub Sektor Makanan Dan Minuman Yang Terdaftar Di Bursa Efek Indonesia (Periode 2012-2016). Jurnal Akuntansi Dan Keuangan, 5(1), 59. 